University for Business and Technology in Kosovo

UBT Knowledge Center

UBT International Conference

2018 UBT International Conference

Oct 27th, 1:30 PM - 3:00 PM

\title{
Maxim de Winter's perception of the female world in Du Maurier's Rebecca
}

Silvishah Miftari Goodspeed

Nova International School, silvishahm@gmail.com

Follow this and additional works at: https://knowledgecenter.ubt-uni.net/conference

Part of the Education Commons

\section{Recommended Citation}

Goodspeed, Silvishah Miftari, "Maxim de Winter's perception of the female world in Du Maurier's Rebecca" (2018). UBT International Conference. 128.

https://knowledgecenter.ubt-uni.net/conference/2018/all-events/128

This Event is brought to you for free and open access by the Publication and Journals at UBT Knowledge Center. It has been accepted for inclusion in UBT International Conference by an authorized administrator of UBT Knowledge Center. For more information, please contact knowledge.center@ubt-uni.net. 


\title{
Maxim de Winter's Perception of the Female World in Du Maurier's Rebecca
}

\author{
Silvishah Miftari Goodspeed \\ Nova International Schools, Skopje \\ silvishahm@gmail.com
}

\begin{abstract}
Rebecca is a novel written by Daphne Du Maurier, in which the main characters are women. This paper focuses on the only male point of view, Maxim de Winter's. He was Rebecca's husband and he is the spouse of the current Mrs. de Winter. He is also Mrs. Danvers' landlord, Beatrice's brother, and Mrs. Van Hopper's acquaintance. He is the lynchpin uniting the female characters, whose decisive leadership motivates the novel's action. In the past, critics have often analyzed the plot's female points of view, mentioning Mr. de Winter mainly as an opposite entity to these ladies. This essay examines Maxim's experience of the women who have - apparently, against his willtaken over and decided about his adult life. This paper's primary aim is to introduce into the criticism the figure of Maxim de Winter as a stronger masculine character in a novel dominated by women and their preponderant presence.
\end{abstract}

Keywords: Rebecca, Du Maurier, de Winter, Manderley.

\section{Introduction: the meaning of Rebecca through the author's eyes}

Maxim de Winter is one of the main characters of Du Maurier's most famous novel, Rebecca. George Fortescue Maximilian "Maxim" de Winter is a 42-year-old and very rich widower in a novel written by a female writer where almost all the main characters are women. Even if the work is strongly characterized by the ubiquitous female presence, there was need also for a male voice, even if his presence has been delivered to the readers through the eyes of the narrator, who is (again a female role, i.e.) the second Mrs. De Winter.

Maxim is a character who in certain ways resembles his author: they are both relatively young (Daphne du Maurier was only 31 when the novel was published), they both come from wealthy families, and they are both very attached to their quiet and private lives. Even their main residence seems to travel from real life to fiction, changing slightly its name from Milton Hall and Menabilly to Manderley. The main difference between the creator and its creature is that Maxim lives through the eyes, feelings and experience of other characters, he has no freedom whatsoever; and yet he 
is essential for the development of the plot. Du Maurier, on the other hand, preserved a certain level of complete independence throughout her adult life, becoming famous as (later, Dame) Daphne Du Maurier, instead of Lady Browning, or the wife of Lieutenant-General Sir Frederick Arthur Montague "Boy" Browning.

Rebecca was started in Egypt, after her husband has been deployed in the North of Africa, and Daphne, at that point already his wife, had to follow him. She felt continuously homesick, regardless, and despite all the distractions and amusements she could have enjoyed as a foreigner, and the wife of a man with a high military rank. It was then that Miss Du Maurier decided to write a new novel, and she set it in Cornwall, the part of England she loved above all the others. Even if started abroad, the book has been finished in England. "In April 1938, Daphne finally writes to her editor: Here is the book. I've tried to get an atmosphere of suspense. It's a bit on the gloomy side. The ending is a bit brief and a bit grim." (de Rosnay 2017: 143) Once published, the book brought to its author international fame, improving significantly also her personal financial situation. Daphne Du Maurier was not anymore only the daughter of Sir Gerald Du Maurier, the renowned London actor and manager, now she became known not only as a fine writer, but more than anything she was now known as the author of the acclaimed Rebecca.

\footnotetext{
"Last night I dreamt I went to Manderley again. The famous opening line of Daphne du Maurier's novel Rebecca has a sinister, haunting melancholy that heads straight to the spirit and the center of her private world. If she had written just this one work she would still be remembered as a truly great storyteller for it is with this novel more than any other that she is identified. None of her others has Rebecca's power and strength. It has been outstanding at six levels of entertainment: as a best-selling novel, a radio series, a Hollywood motion picture, a stage play, a television series and even as an opera." (Shallcross 1991: 59)
}

Daphne du Maurier wrote many books, but Rebecca remains her most famous work - it is enough to mention that the book has never been out of print since it first appeared in 1938. Set in Cornwall (like six among her other novels), this little giant has been named after a dead first wife, and its story has been told by the nameless second wife. "(...) like the later Rebecca, (...) deals with a young woman alone in the world, cast adrift in an unfamiliar, hostile environment." (Shallcross 1991: 49) It is Maxim De Winter who introduces the narrator to his, i.e. Rebecca's life at Manderley, and it is always Maxim who is, indirectly, brought to ruin, as a punishment for having forgotten the perfect, yet to him obnoxious first wife, and for having replaced her with a sloppy, frightened, and very young second wife. "Rebecca is a grim anatomy of wifehood. Rebecca the dead, bad wife exists only as a hovering name; the good second wife, who tells the story, has no name and little energy." (Auerbach 2000: 1-2) De facto, it is Maxim the connection (together with the invented Cornish estate of Manderley) the connection not only between the two wives, but all the main female characters revolve around this triangle of personalities, and their base, the big, old De Winter's house. 


\section{Maxim de Winter and the women of his life}

\subsection{Maxim de Winter}

Maxim makes his entry into the book almost at the beginning, and the importance of his presence is immediately evident. Being presented and described as a character out of the ordinary, as a man out of place in his own century, especially in the hot summer of the Côte d'Azur, his initial lines give space for introductive conjectures. The story is very well known, but what is not so obvious, transpires from what his second wife shares, many times indirectly, with the readers. His surname is the first clue that gives a possible insight into a deeper level of his character: de Winter. An elegant and educated cosmopolite, Maxim seems to be also a cold and solitary man who dislikes crowds and parties. He arrives and stays in Monte Carlo all by himself, and later with the narrator of the story, who soon becomes his (second) wife. Once back at Manderley, Maxim reveals his love for solitude, but also mystery. His feelings towards his new wife are never clear, until he tells her about Rebecca's death - it is only then that Mrs. de Winter gets to know her husband's emotions both towards her, and also all the others living and dead characters.

De Winter exists because there is need for a husband. He is taciturn and mysterious because he hides a serious secret, but what is not transparent is at first his deep dislike of his first wife (it can be called hate as well), and second the fact that he does care a lot about his second wife, who, after he tells her about Rebecca's death, is not treated, pampered and protected like an unexperienced, and too young wife, but she finally takes over the role of a life partner, equal to her husband, and willing to share all their lives and relationship brings them, unafraid of future challenges. Unfolding the truth in front of her eyes, both Mrs. de Winter and the readers discover in Maxim a new level of a more crude humanity, because Maxim is a murderer, regardless his motif and possible justifications. Jealousy, disappointment, and a thick web of lies compose the trigger that unfolds his most secret courage, in committing homicide, and also for living afterwards with that horrible bargain on the conscience.

\subsection{Maxim towards Rebecca de Winter}

Rebecca is the name of the novel, and so it seems to be everything else "Rebecca's writing, Rebecca's desk, Rebecca's diary, Rebecca's last note to her cousin combine to make a theme which runs through the novel." (Shallcross 1991: 64) Rebecca is a novel that never introduces its character because the first Mrs. de Winter is dead when the story begins. She is dead, and yet it seems that everything belongs to her, is dominated by her memory, that is, the fact that none of the other characters can do without her. She is described by others as the perfect woman, the one who covers every role with sophistication, class and elegance. What strikes the most is that it seems that Maxim and Rebecca have not a happy marriage, on the contrary. The readers can not know why Maxim married Rebecca in the first place. Perhaps he was infatuated with her; perhaps he was overruled by passion, or perhaps 
he proposed to her for the sheer pleasure of giving to his masterful mansion a (apparently) perfect mistress, one that everybody would adore and worship, taking her as an example to be followed. "Rebecca is a perfect woman in the novel's first half, then, in the second, she turns into a woman who is perfectly evil, because unwomanly. She is a less coherent character than a series of discordant images." (Shallcross 1991: 121) Maybe these discordant images are too weak to construct a complete character, but they are strong enough to hunt all the other characters, throughout the novel. Maxim never speaks about his first wife, and yet she is always present in his everyday life. When he leaves Manderley for Monte Carlo, he has with himself a book of poems that belonged to Rebecca. When he returns home with his new wife, the disposition of the rooms never changes, nor their furniture, or the way they have been always kept by the first wife. The only difference is that Maxim and his new, nameless wife live in the east wing of the house, while the west one belonged to Rebecca and her husband. There is a hunting question from that point on in the book: why has Maxim never ordered the west wing to be completely changed? Why does he never go there, knowing that Mrs. Danvers (who was obsessed with her mistress) will probably preserve everything as it was before her mistress died? Maxim has murdered Rebecca, and this might be the reason why he avoids everything that belonged to her, and does not change things in order to put to rest his own conscience. Maxim has the strength to continue to love Manderley, to live there, to bring his new wife in those rooms, and even to keep Mrs. Danvers, who continues to run the house as if nothing changed. Such behavior requires bravery, a strong will, and confidence in oneself. Rebecca has ruled over Manderley and all its inhabitants, she has ruled over their relatives and friends, but she has never had too much power over her husband, who not only had the courage to murder her, but also to build a new life with another woman, on Rebecca's things, punishing her forever for her betrayals, and the web of lies in which she entangled him too.

Even if a murderer, Maxim inspires his readers' sympathy, and even compassion, especially at the end when Rebecca, after all, wins against him, and all the others, because Manderley is set to fire. The culprit is unknown, but not so the outcome: Maxim and (the second) Mrs. de Winter leave England for good, leaving isolated in a little, unknown Mediterranean locality, cut from everybody and everything.

\subsection{Maxim towards Mrs. de Winter}

Daphne Du Maurier said about her most famous work that "I began the novel in the first person and I avoided giving the heroine a name because it became an interesting exercise in writing and technique." (Shallcross 1991: 68) Who is this young, clumsy, insecure lady who becomes the second Mrs. de Winter? “(...) there is no escape for a woman. There is certainly none for the wife who tells the story of Rebecca. Throughout the novel she is a docile companion to the overbearing rich first to a dreadful American, Mrs. Van Hopper, and then, as a wife, to the beautifully mannered landowner Maxim de Winter - with no control over the plot in which Maxim presides and falls." (Auerbach 2000: 102) The young woman who is one of the main characters in the novel, and also its narrator, has in reality no name, she is 
described as insecure, clumsy, and not very pretty, and yet Maxim chooses her as his new bride, surprising all the other characters in the novel. This surprise has no effect on the reader, especially in the second part of the novel, when we discover the relationship Maxim and Rebecca had, and how she died. Actually, Mrs. de Winter is the only person towards whom Maxim shows complete rule, without ever questioning his own behavior. Since the moment he meets her, he is the one who casts his power on her: he does not propose matrimony in a traditional way:

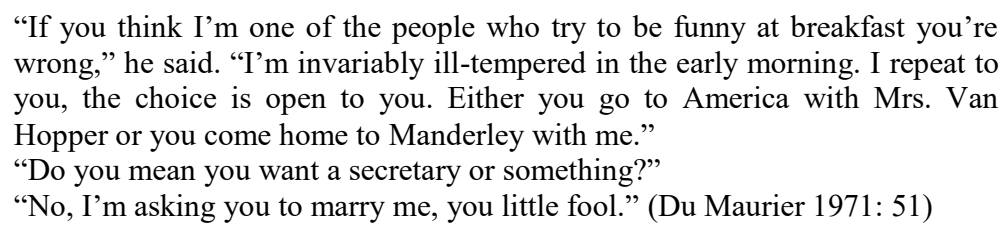

And he continues:

"So that's settled, isn't it?" he said, going on with his toast and marmalade; "instead of being companion to Mrs. Van Hopper you become mine, and your duties will be almost exactly the same. I also like new library books, and flowers in the drawing-room, and bezique after dinner. And someone to pour out my tea. The only difference is that I don't take Taxol, I prefer Eno's, and you must never let me run out my particular brand of tooth-paste." (Du Maurier 1971: 53)

Maxim's attitude does not change towards his second wife until he confesses to her Rebecca's murder. Only afterwards, when she is sure about his feelings towards her, does Mrs. de Winter acquire a stronger personality where, by the end of the book, she is the one taking care of Maxim, and not anymore the vice versa. It is interesting that the change in him occurs suddenly and only because Rebecca's body emerges out of the waters. Readers rightly ask themselves what would have happened if Rebecca had not decided for the last, great revenge. Most likely the other characters would have remained unchanged over time, except, perhaps, Mrs. Danvers, who has always been too fond to her previous mistress to calmly endure the presence of the new comer. These are and remain conjectures, since the plot has been developed differently.

\subsection{Maxim towards Mrs. Van Hopper, Mrs. Danvers, and Beatrice}

Mrs. Van Hopper is a figure present only in the opening chapters of the novel, as her presence is needed for the introduction of the relationship between Maxim and Mrs. de Winter. Mrs. Van Hopper was a wealthy American woman, vacationing on the French Riviera with her young companion. She has been described as foolish, shallow, and insensitive, but is also she who will provide, though indirectly, Maxim with a new wife. Maxim treats the old lady from the very beginning with perfect curtesy, though veiled with irony. He treats her just like everyone else, with pride, but also keeping her away from his personal world and feelings. He has no consideration for the old lady, and starts a platonic relationship 
with the young companion without ever considering possible consequences on Mrs. Van Hopper's life. He dislikes her, but is also polite enough never to show his real opinion.

When it comes to Beatrice, Maxim's sister, his figure changes very little. Her purpose in the plot might be very simple: she is the one who, through the narrator's words, unfolds another piece of the Maxim's and Rebecca's seemingly perfect marriage. Just like with his own wife (at least in the first part of the book), Maxim is not a very affectionate brother, and meets the sister only a few times every year, more for conventions and family ties, than by character affinity. When the narrator meets her sister in law, Beatrice is reasonable, and good-tempered enough to accept her brother's second choice (even if it seems that, like almost everyone else, she used to adore Rebecca), and encourage their union.

Mrs. Danvers is the last of the main characters, together with her lord and his wives. From the very beginning of her introduction in the plot, it is obvious that Mrs. Danvers (called "Danny" by Rebecca and her cousin) was more than fond of her young mistress - she was obsessed with her appearance and character, helping her to cover all her mischiefs. Maxim has never had problems or issues of any kind with the maid, though it is important to notice that he respected her, but kept her too on a distance, probably because he was afraid that sooner or later she would discover the truth. Mrs. Danvers never shoes her true fillings towards her landlord, though she clearly dislikes his second, young bride, probably considering that her landlord forgot Rebecca too soon, and married someone who was clearly under her league. Mrs. Danvers and Maxim have a cold and distant relationship, without apparent conflicts, but her influence over the young Mrs. de Winter has consequences over Maxim as well, because through his new young bride, Mrs. Danvers does not let him forget her beloved Rebecca.

\subsection{Conclusion}

Rebecca is a multi-faceted novel, and asserting that it simply treats the story of a man and his two wives would be too restrictive. The novel can be analyzed following various interpretations - this short essay wanted to underline the importance of Maxim de Winter in the plot of the work, following both his personality and the one of the women who characterized the unfolding of events in the life of the only male protagonist of the story. Each one of them has left a mark in his life. Sometimes deliberately, others unconsciously, these women have influenced his decisions and behaviors, leading Maxim to a financial ruin, and destroying the good name of his ancient family. What stroke him the most was the physical destruction of his beloved Manderley, set on fire, even if it has never been known by who was set the burning. At the end, Maxim is reduced to live in an anonymous hotel in the Mediterranean, secluded by his own will and attended by his second wife, and probably like her, living of memories and regrets, waiting, by now, only death. 


\section{References}

1. Nina Auerbach, Daphne du Maurier, Haunted Heiress, University of Pennsylvania Press, Philadelphia, 2000.

2. Tatiana de Rosnay, Manderley Forever, A Biography of Daphen Du Maurier, (Translated from the French by Sam Taylor). St. Martin's Press, New York, 2017.

3. Daphne Du Maurier, Rebecca, Avon Books, New York, 1971

4. Daphne Du Maurier, Growing Pains, the Shaping of a Writer. Victor Gollancz Ltd, London, 1977.

5. Martin Shallcross, The Private World of Daphne du Maurier, St. Martin Press, New York, 1991 